\title{
IMPACT OF NATURAL BINDER ON PELLET QUALITY
}

\section{Agnieszka ZDANOWICZ, Jerzy CHOJNACKI}

Mechanical Department, Koszalin University of Technology, POLAND

E-mail of corresponding author: agnieszka.zdanowicz@s.tu.koszalin.pl

Keywords: straw waste management, biomass fuel, rape straw, mechanical performance

\begin{abstract}
Production of energy pellets from waste straw is a good way to manage the straw surplus and to increase profitability of the agricultural enterprises. The present paper covers the results of the tests of the hardness of pellet made from a mixture of rape straw with an addition of wheat flour as a natural binder. The samples of raw material for the production of pellet included $0.0 \%, 4.1 \%$ and $7.8 \%$ of wheat flour, which was determined according to dry matter. The average relative humidity of the raw material samples was: $11.6 \%, 22.3 \%$ and $30.7 \%$. The measurement of the pellet hardness was performed with the aid of the Kahl method. The influence was found of wheat flour contents and the relative humidity of the mixture on the increased hardness of pellet.
\end{abstract}

\section{INTRODUCTION}

The management of straw resources is an important problem for farms. In the sustainable agriculture, the part of the straw can be plowed after harvesting, thereby enriching the humus layer of the soil. The remaining part can be converted into fuel pellets for boilers. Instead of purchase fuel, for example coal, farmers can produce own fuel, improving this way farms economic performance and at the same time producing source of "green energy". In the recent years, the production and use of pellet from biomass as a fuel has considerably increased. Those boilers with maintenance-free mechanical fuel supply and automatic ignition which are used for its combustion, and which offer the possibility of continuous heating work, require good quality fuel granulate. These requirements are related not only to its thermochemical properties but also to mechanical properties. Fuel granulate needs to be durable and it should not suffer from damage during transport, handling and storing. The problem of the quality of fuel pellet is particularly important when it is used in boilers in individual heating of flats because large heating plants have considerably more advanced systems of fuel supply and process control. To improve the mechanical properties of pellet, apart from the selection of technical parameters for the pelletisation process, binding agents are used that increase pellet hardness (e.g., Obernberger \& Thek, 2004; Razuan et al., 2011; Emadi et al., 2017). Pellet additions can also be used to improve its combustible properties (e.g., Chyc, 2012, Tarasov et al., 2013). Many types of materials which can be used to bind biomass together in energy pellet are commonly used in feed industry as the elements of granulate for livestocks. They perform there nutritional functions, but they also act as binders and enhance the structure of pellet (e.g., Gehring et al., 2009; Obidziński \& Hejft, 2012).

An excess of straw from agricultural production is a favorable factor for its use as a raw material in the production of pellet biofuel. For this reason, research is conducted to invent formulae for good quality energy pellet from this raw material (e.g., Döring, 2013; Lu et al., 2014).

The purpose of the research was the strength assessment of pellet from rape straw that is made solely from straw with an addition of wheat flour, with different humidity degrees of the of raw material and with various contents of flour. 


\section{MATERIAL AND METHODS}

Rape straw from rapeseed cakes was used to make the raw material for pellet. After grinding the straw with the dry oven test, its relative humidity and the relative humidity of wheat flour were determined, which were $11.8 \%$ for rape straw and $6.75 \%$ for flour. Apart from rape straw, a mixture of rape straw and wheat flour was prepared for the production of pellet. Each sample included $700 \mathrm{~g}$ of straw. Water in the quantity of 100 $\mathrm{ml}$ and $200 \mathrm{ml}$ and wheat flour in the quantity of $28 \mathrm{~g}$ and $56 \mathrm{~g}$ were added to part of the samples. This corresponded to 4 and $8 \%$ of the share of rape straw. During the preparation of the samples, the humidity of straw and flour was omitted. The percentage shares of straw and flour were converted into the shares of dry matter of those elements which, after conversions, were as follows: $0 \% ; 4.1 \% ; 7.8 \%$. The resulting relative humidity of each of the samples and the average relative humidity were also calculated depending on the capacity of water added. The composition of the samples prepared and their humidity is presented in Table 1.

Table 1. Parameters of the mixture of chopped rape straw and wheat flour

\begin{tabular}{|c|c|c|c|c|c|c|}
\hline \multicolumn{4}{|c|}{ Content } & \multirow[t]{2}{*}{$\begin{array}{l}\text { Additional } \\
\text { water }\end{array}$} & \multirow[t]{2}{*}{$\begin{array}{l}\text { Moisture } \\
\text { content }\end{array}$} & \multirow{2}{*}{$\begin{array}{l}\text { Average } \\
\text { moisture } \\
\text { content }\end{array}$} \\
\hline rape straw & flour & $\begin{array}{c}\text { rape straw } \\
\text { (dry matter) }\end{array}$ & $\begin{array}{l}\text { flour (dry } \\
\text { matter) }\end{array}$ & & & \\
\hline $\mathrm{g}$ & $\mathrm{g}$ & $\%$ & $\%$ & $\mathrm{ml}$ & $\%$ & $\%$ \\
\hline 700 & 0 & 100.0 & 0.0 & 0 & 11.8 & \multirow{3}{*}{11.6} \\
\hline 700 & 28 & 95.9 & 4.1 & 0 & 11.6 & \\
\hline 700 & 56 & 92.2 & 7.8 & 0 & 11.4 & \\
\hline 700 & 0 & 100.0 & 0.0 & 100 & 22.8 & \multirow{3}{*}{22.3} \\
\hline 700 & 28 & 95.9 & 4.1 & 100 & 22.3 & \\
\hline 700 & 56 & 92.2 & 7.8 & 100 & 21.8 & \\
\hline 700 & 0 & 100.0 & 0.0 & 200 & 31.4 & \multirow{3}{*}{30.7} \\
\hline 700 & 28 & 95.9 & 4.1 & 200 & 30.7 & \\
\hline 700 & 56 & 92.2 & 7.8 & 200 & 30.0 & \\
\hline
\end{tabular}

After 72 hours (the time that was considered to be required for water to penetrate into the structure of the mixture), the pellet was made from the mixtures with the use of a disc pelletizer with the diameter of $6 \mathrm{~mm}$ pelletising holes. The pellet obtained was dried off to zero relative humidity and then its specific density and bulk density were determined. The results are presented in Table 2 . The methodology included in papers (Lam et al., 2008; Roman, 2016) was used in the measurement of the volumetric mass density of the pellet.

The hardness of pellet was measured with the use of the Kahl hardness tester by determining its destructive force in Newtons. Methodology was described by Obidziński (2014). The measurement was repeated 25 times for each kind of granulate obtained from nine samples of the raw material.

Table 2. Average density of the granulate obtained (measurement performed on dry matter)

\begin{tabular}{|c|c|}
\hline \multicolumn{2}{|c|}{ Pellet } \\
\hline Bulk density & $\begin{array}{c}\text { Volumetric mass } \\
\text { density }\end{array}$ \\
\hline $\mathrm{kg} \cdot \mathrm{m}^{-3}$ & $\mathrm{~kg} \cdot \mathrm{m}^{-3}$ \\
\hline 396.8 & 840 \\
\hline
\end{tabular}




\section{RESULTS AND DISCUSSION}

The results obtained of the measurements of the pellet strength according to Kahl were subject to a statistical analysis to determine the significance of the impact of the addition of wheat flour and the relative humidity of the material on the pellet hardness. With the use of the variance analysis, the significance (with statistical significance $\mathrm{p}<0.05$ ) was determined of the impact of wheat flour and the relative humidity of the material on the hardness of pellet. The calculated least significant difference (LSD) was calculated in the hardness of the granulate both for the first factor, i.e. the percentage content of wheat in the material and for the second factor: the relative humidity of the material was LSD $=19.581$. The test results for the impact of the content of the binder addition (wheat flour) on the hardness of the granulate are presented in Fig. 1. The significant change in the pellet hardness occurred between the content of flour according to dry matter of zero and $4.1 \%$. An increase of the content of flour in the raw material up to $7.8 \%$ increased the pellet hardness, yet the difference in the hardness value between the contents: 4.15 and $7.8 \%$ did not exceed the LSD value.

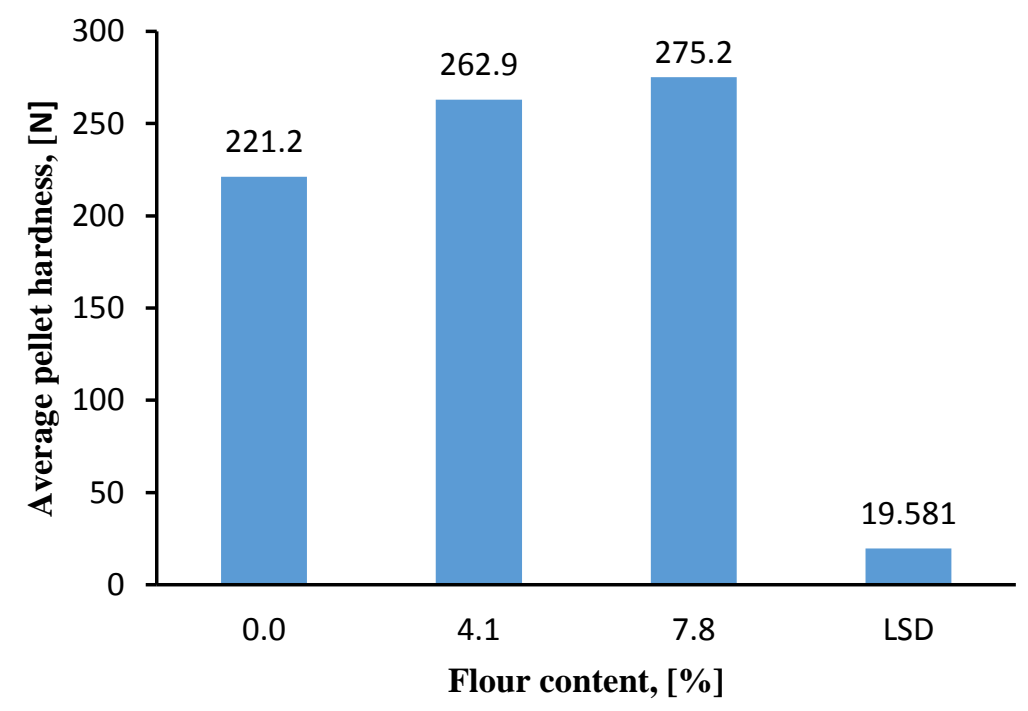

Fig. 1. Impact of wheat flour content in the raw material on the average pellet

In the case of an addition of water to the raw material, it may be stated that the hardness of pellet significantly grew with an increase of the relative humidity of the material (Fig. 2). This was most probably because the addition of water to the mixture had a positive influence on the binding properties of the flour.

When analyzing the diagram of the impact both of the flour content and the raw material humidity, which is presented in Fig. 3, it may be generally stated that the impact of such factors such as the raw material humidity and the flour content in the raw material on the hardness of pellet is interrelated. It can also be observed that with the relative humidity of the raw material of $22.3 \%$, the content of the binder, i.e. wheat flour, had the smallest impact on the hardness of pellet, where straw from rapeseed cake was the main raw material. The diagrams in Fig. 3 furthermore demonstrate that an increase of the raw material humidity from $11.6 \%$ to 22.3 would always result in a significant increase of the granulate hardness. 


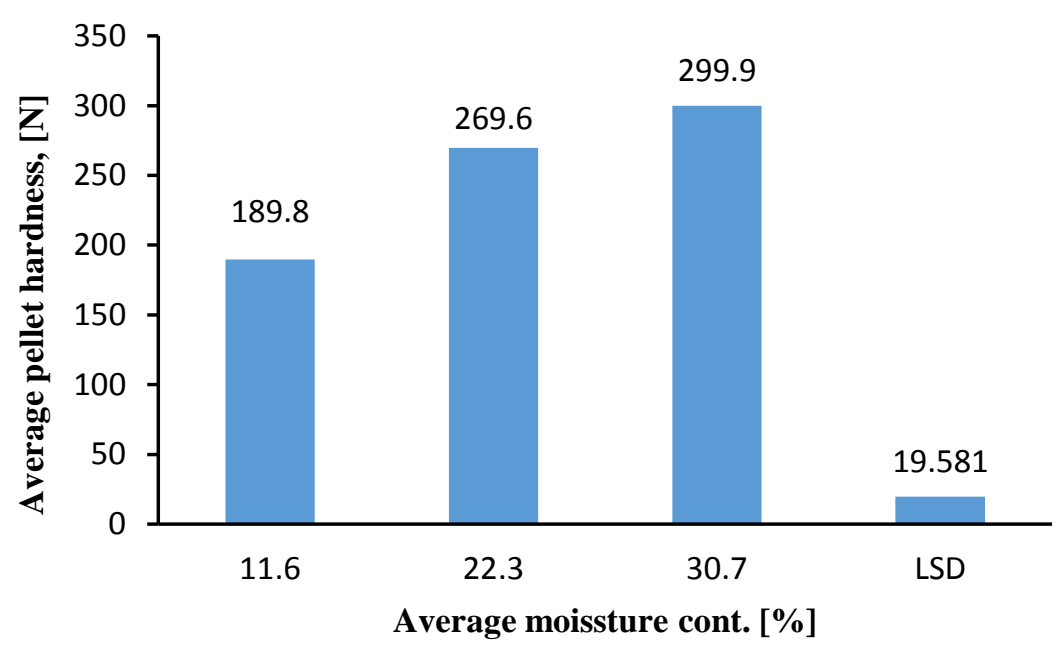

Fig. 2. Impact of average relative humidity of raw material on the average hardness of pellet produced

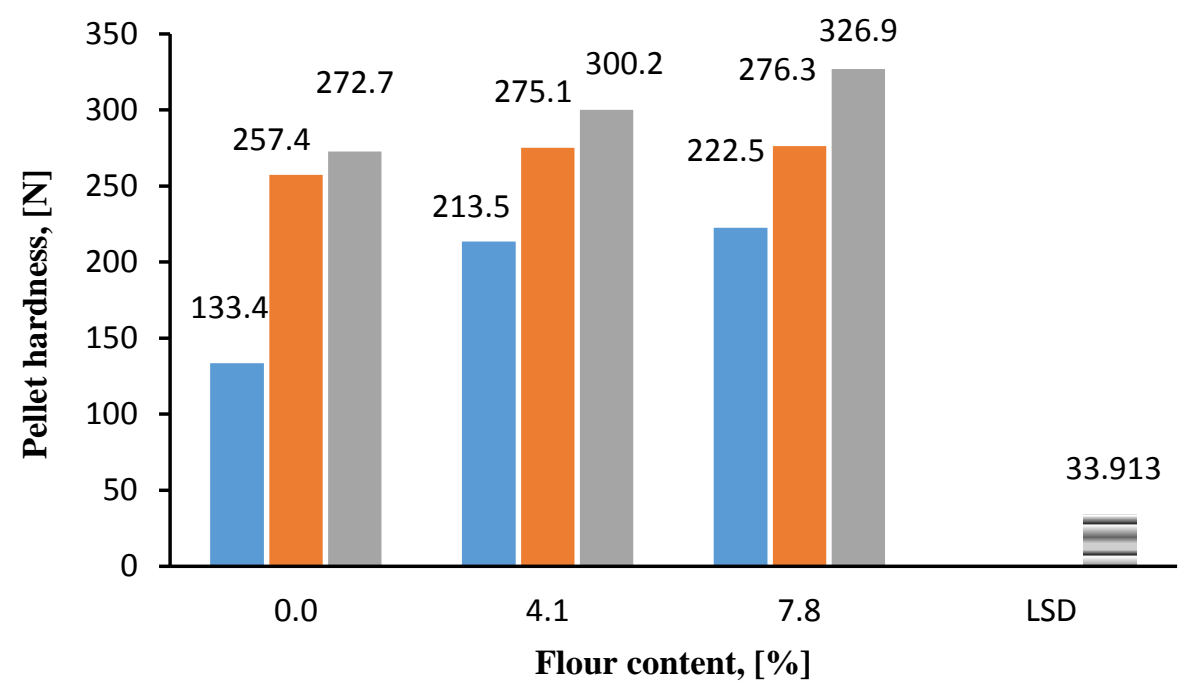

Moisture cont. $13.3 \% \quad$ Moisture cont. $16.9 \% \quad$ Moisture cont. $30.7 \%$

Fig. 3. Impact of wheat flour content in raw material and relative humidity on pellet hardness

Increasing the relative humidity of the raw material more than $22.3 \%$ significantly influenced the growth of the pellets hardness, but only at the content of flour $7.85 \%$ degrees of the of raw material and with various contents of flour.

\section{CONCLUSIONS}

A significant impact was established of wheat flour content and the raw material humidity on the hardness of the granulate produced from rape straw with an addition of wheat flour. The pellet hardness increased significantly with greater contents of the wheat flour addition and with greater humidity of the raw material. Even a small amount of flour addition (about $4 \%$ of dry mass) can significantly increase the hardness of the granulate. Adding wheat flour as a binder above $4.1 \%$ does not guarantee a significant increase the pellet hardness. 
Addition of water to the raw material influenced on the binding properties of the flour but raises the humidity of the pellet. The addition of water to rape straw and to mixture of straw and flour (to the relative humidity of $22.3 \%$ ) always significantly increased the hardness of the pellet. Higher relative humidity (between $22.3-30.7 \%$ ) of the raw material with wheat flour $7.8 \%$ raised the hardness of pellet. This indicates that the significant impact on the hardness of the granulate, made from mixture of wheat flour and rape straw, was as a result from appropriately added quantity of water depending on the flour content degree inside of the raw material.

Research has shown that it is possible to manage the waste of rape straw as a source of "green energy". Research has shown also that there is possibility producing pellet with good mechanical parameters from the waste using natural binders.

\section{ACKNOWLEDGMENTS}

The subject of research was inspired by the Polish-Slovak project SK-PL-2015-0059, conducted in the years of 2016-17 and entitled "Development of low-emission solid fuels from biomass residues".

\section{REFERENCES}

Chyc M. (2012). Znaczenie dodatków paliwowych w procesach spalania paliw stałych. Prace Naukowe GIG. Górnictwo i Środowisko,1, 5-16.

Döring S. (2013). Fuel Quality Requirements in; Power from Pellets: Technology and Applications. ISBN 978-3-642-19961-5, 61-69.

Emadi B., Iroba K. L. \& Tabil L. G. (2017). Effect of polymer plastic binder on mechanical, storage and combustion characteristics of torrefied and pelletized herbaceous biomass. Applied, 198, 312-319.

Gehring C. K., Jaczynski J. \& Moritz J. S. (2009). Improvement of pellet quality with proteins recovered from whole fish using isoelectric solubilization-precipitation. Appl. Poult. Res., 18, 418-431.

Lam P. S., Sokhansanj S., Bi X., Lim C. J., Naimi L. J., Hoque M., Mani S., Womac A. R., Ye X. P. \& Narayan S. (2008). Bulk density of wet and dry wheat straw and switchgrass particles. Applied Engineering in Agriculture, 24 (3), 351-358.

Lu D., Tabil L. G., Wang D.,Wang G. \& Emami S. (2014). Experimental trials to make wheat straw pellets with wood residue and binders. Biomass and Bioenergy, 69, 287 - 296.

Obernberger I. \& Thek G. (2004). Physical characterisation and chemical composition of densified biomass fuels with regard to their combustion behaviour. Biomass and Bioenergy, 27, (6), 653-669.

Obidziński S. (2014). Badania porównawcze metod oceny wytrzymałości kinetycznej granulatu. Inżynieria Przetwórstwa Spożywczego, 2/4, 26-29.

Obidziński S. \& Hejft R. (2012). Wpływ parametrów techniczno-technologicznych procesu granulowania pasz na jakość otrzymanego produktu. Journal of Research and Applications in Agricultural Engineering, 57, (1), 109-114.

Razuan R., Finney K. N., Chen, Q., Sharifi V. N. \& Swithenbank J. (2011). Pelletised fuel production from palm kernel cake. Fuel Process. Technol., 92 (3), 609-615.

Roman K. (2016). Gęstość właściwa cząstek biomasy pochodzenia leśnego o różnych wymiarach i wilgotności pomniejszona o objętość porów wewnętrznych. Problemy Inżynierii Rolniczej, 2 (92), 85-92.

Tarasov D., Shahi C. \& Leitch M. (2013). Effect of Additives on Wood Pellet Physical and Thermal Characteristics: A Review. Hindawi Publishing Corporation ISRN Forestry, Article ID 876939, available: http://dx.doi.org/10.1155/2013/876939 